\title{
STRATEGI PENINGKATAN PRODUKTIVITAS DAN KUALITAS KEDELAI LOKAL DENGAN PENDEKATAN PRODUKTIVITAS HIJAU
}

\section{STRATEGIES FOR INCREASING LOCAL SOYBEAN PRODUCTIVITY AND QUALITY WITH A GREEN PRODUCTIVITY APPROACH}

\author{
Kardiyono $^{1)^{*}}$, Marimin ${ }^{2)}$, Nastiti Siswi Indastri' ${ }^{2)}$, Indah Yuliasih ${ }^{2)}$, Gatot Pramuhadi ${ }^{3)}$ \\ ${ }^{1)}$ Balai Pengkajian Teknologi Pertanian Banten Jl. Ciptayasa Km 01 Ciruas Serang \\ Email : kardiyono70@gmail.com \\ ${ }^{2}$ Departemen Teknologi Industri Pertanian, Fakultas Teknologi Pertanian, Institut Pertanian Bogor \\ ${ }^{3}$ Departemen Teknik Mesin dan Biosistem, Fakultas Teknologi Pertanian Institut Pertanian Bogor \\ Makalah: Diterima 27 Agustus 2018; Diperbaiki 2 November 2018; Disetujui 20 November 2018
}

\begin{abstract}
Increasing the competitiveness of soybean is an important thing and priority that must be done in order to fulfil the national food security. The objectives of the research were (1)to map of local soybean problems associated with the concept of green productivity, (2) performance / green productivity index of soybean cultivation, and (3) design model of increasing soybean green productivity. The research was conducted in Banten Province on soybean production center. Data and information were collected through interviews and indepth discussions on soybean business actors. The methods used were Green Value Mapping system, Green Produtivity Indeks, and Fuzzy Inference System (FIS). The results showed that the green productivity status of soybean agribusiness was in low category that need to be improved through innovation especially on seed supply, post harvest handling, and utilization of waste.
\end{abstract}

Keywords : soybean, competitiveness, green productivity, green value stream mapping, fuzzy inference system

\section{ABSTRAK}

Peningkatan daya saing kedelai merupakan hal penting dan prioritas yang harus dilakukan guna mewujudkan ketahanan pangan nasional. Penelitian ini bertujuan untuk: (1) melihat peta permasalahan kedelai lokal dikaitkan dengan konsep produktivitas hijau, (2) mengukur perfomansi / indeks produktivitas hijau bagian budi daya kedelai, dan (3) membuat model peningkatan indeks produktivitas hijau kedelai. Penelitian dilakukan di Provinsi Banten pada sentra produksi kedelai. Data dan informasi dikumpulkan melalui wawancara dan diskusi mendalam terhadap pelaku usaha kedelai. Metode yang digunakan adalah Green Value Mapping system dan Fuzzy Inference System (FIS). Hasil penelitian menunjukkan bahwa status produktivitas hijau pada usaha kedelai berada pada katagori rendah dan perlu ditingkatkan melalui inovasi terutama pada aspek penyediaan benih, penanganan pascapanen, dan pemanfaatan limbah.

Kata Kunci : kedelai, daya saing, produktivitas hijau, green value stream mapping, fuzzy inference system

\section{PENDAHULUAN}

Penurunan produksi kedelai lokal dan peningkatan kedelai impor merupakan salah satu indikasi lemahnya daya saing kedelai lokal terhadap kedelai impor. Tasra et al. (2012) mengemukakan keberlanjutan produksi kedelai lokal dinilai rendah akibat kebijakan pemerintah yang tidak menerapkan tarif impor sejak tahun 1998. Produksi kedelai menurun karena petani tidak tertarik untuk menanam kedelai (Supadi, 2009; Zakaria et al., 2010). Ketergantungan impor kedelai dapat berisiko terhadap ketahanan nasional dan stabilitas sosial, ekonomi, dan politik sehingga perlu diarahkan menuju swasembada (Supandi, 2009). Langkah strategis yang dilakukan menuju swasembada kedelai yaitu dengan memberdayakkan semua komponen teknologi secara simultan agar memberikan dampak terhadap petani sebagai produsen kedelai dan juga pengrajin tahu dan tempe sebagai konsumen (Tasra et al., 2012). Peningkatan daya saing kedelai lokal dapat juga dilakukan dengan menggali keunggulan dan mengoptimalkan kedelai lokal untuk memenuhi kebutuhan pasar.

Tren konsumen saat ini dan ke depan yang peduli terhadap produk sehat dan ramah lingkungan dapat dijadikan pendorong dalam memproduksi kedelai lokal (Karmala, 2009; Sumarno, 2010; Muslim dan Diah, 2014). Ginting et al. (2009) menyatakan bahwa kedelai lokal memiliki beberapa keunggulan yaitu kedelai non transgenik sehingga aman dikonsumsi, memiliki tingkat kesegaran, rendemen, dan kandungan protein yang lebih tinggi dibandingkan kedelai impor. Di sisi lain, kedelai lokal masih memiliki kelemahan antara lain masih rendahnya kualitas kedelai berupa tingginya kadar air dan kotoran serta biji yang tidak seragam.

Pendekatan produktivitas hijau merupakan pendekatan guna meningkatan kinerja produktivitas dan lingkungan untuk pembangunan sosial-ekonomi (Saxena et al., 2003). Produktivitas hijau 
didefinisikan sebagai strategi peningkatan kinerja produktivitas dan lingkungan untuk pembangunan sosial ekonomi secara keseluruhan. Produktivitas hijau merupakan aplikasi alat, teknik, metodologi dari produktivitas dan manajemen lingkungan yang tepat untuk mengurangi dampak lingkungan (Marimin et al., 2015). Konsep produktivitas hijau dapat diimplementasikan untuk meningkatkan daya saing kedelai lokal. Hal ini sejalan dengan permasalahaan kedelai lokal yang produktivitas dan kualitasnya masih rendah serta belum optimalnya pemanfaatan sumber daya dalam produksi. Hal penting lain yang relevan dengan konsep produktivitas hijau yaitu masih terdapat pemborosan dalam sistem produksi kedelai yang mengarah pada terjadinya kerusakan lingkungan.

Produksi kedelai dapat dilakukan pada tiga tipe lahan yaitu lahan sawah, lahan tegalan, dan lahan hutan. Sebagian besar $(60 \%)$ produksi kedelai dilakukan di lahan sawah dengan cara mengatur rotasi tanam (padi-kedelai-palawija lain atau padipadi-kedelai). rotasi tanam kedelai setelah sawah telah menjadi tradisi di beberapa wilayah dengan maksud memanfaatkan lahan dengan waktu yang singkat (2-3 bulan) untuk mendapatkan pendapatan tambahan. Pola tanam pada lahan hutan biasanya dengan memanfaatkan lahan di antara tanaman hutan yang masih muda. Sedangkan pada lahan tegalan umumnya dilakukan rotasi tanam padi gogokedelai/jagung. Input produksi dan penerapan teknologi budi daya kedelai pada ketiga tipe lahan tersebut berbeda-beda dan menghasilkan produktivitas, nilai ekonomi, serta dampak terhadap lingkungan yang berbeda.
Marimin et al. (2015) menyatakan dalam praktiknya produktivitas hijau terdapat 4 (empat) hal yang menjadi ciri yaitu: (1) pendekatan berbasis orang yang terintegrasi, (2) peningkatan produktivitas, (3) peningkatan informasi sebagai faktor pendorong dan (4) kesesuaian lingkungan. Implementasi produktivitas hijau pada kedelai diharapkan dapat meningkatkan daya tarik konsumen akan kedelai lokal sehingga memotivasi petani untuk menanam kedelai. Tujuan penelitian adalah untuk mendapatkan (1) peta permasalahan kedelai lokal dikaitkan dengan konsep produktivitas hijau, (2) perfomansi / indeks produktivitas hijau bagian budi daya kedelai, dan (3) model peningkatan indeks produktivitas hijau kedelai.

\section{METODE PENELITIAN}

\section{Kerangka Penelitian}

Peningkatan daya saing kedelai lokal melalui pendekatan produktivitas hijau sejatinya berupaya untuk meningkatkan produktivitas dan kualitas kedelai sehingga mampu mengangkat nilai ekonomi dan mendorong motivasi petani untuk mengembangkan kedelai secara luas dan meningkatkan preferensi kalangan industri terhadap kedelai lokal sebagai bahan baku. Kerangka penelitian diawali peniliaan produktivitas hijau menggunakan analisis peta aliran nilai hijau (Green VSM) dan Indeks Produktivitas Hijau. Selanjutnya dilakukan simulasi peningkatan produktivitas hijau dengan fuzzy inferensi system (FIS). Kerangka pemikiran penelitian dapat dilihat pada Gambar 1 .

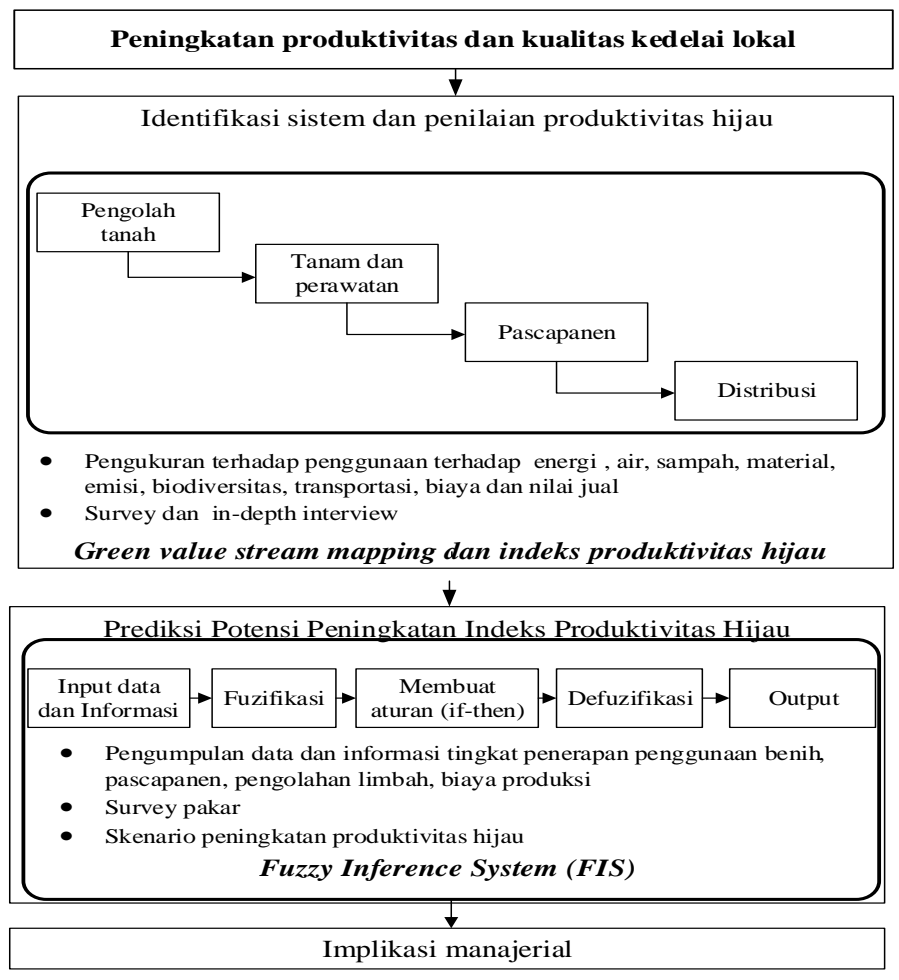

Gambar 1. Kerangka pemikiran penelitian 


\section{Lokasi dan Metode Pengumpulan Data}

Penelitian dilakukan di Provinsi Banten yaitu pada sentra produksi kedelai di Kabupaten Serang dan Kabupaten Pandeglang. Data dikumpulkan melalui survei dan wawancara mendalam terhadap berbagai unsur yang terkait dengan perkedelaian yaitu petani (30 org), pengumpul (4 org), Pengrajin tahu (10), Penyuluh (10 org), Koperasi tahu dan tempe (2 org), Peneliti (3 org) dan pejabat pemda (5 org). Penelitian dilaksanakan pada bulan Juni-Desember 2017.

\section{Metode Analisis Data}

Peta Aliran Nilai Hijau (Green Value Stream Mapping /GVSM)

Peta aliran nilai hijau (Green VSM) merupakan pengembangan dari peta aliran nilai (VSM) yang memperhatikan aspek dampak aktivitas pada lingkungan. VSM menititikberatkan pada pengurangan limbah produksi yang diterjemahkan sebagai pemborosan, sedangkan GVSM berusaha mengurangi limbah lingkungan. Metode pemetaan ini dikembangkan oleh Wills (2009) sebagai teknik untuk menerapkan prinsip green intenstion (Marimin et al., 2015). Pada GVSM terdapat tujuh sumber pembangkit pemborosan yang terdiri dari pemakaian energi, air, mineral, sampah, transportasi, emisi, dan biodiversitas. Selanjutnya dilakukan pemetaan pada saat ini (current state) dan pemetaaan masa yang akan datang (future state) seperti tersaji pada Gambar 2.

\section{Perhitungan Indeks Produktivitas Hijau}

Indeks produktivitas hijau merupakan ukuran dari dua dimensi yang berbeda, yaitu dimensi perlindungan lingkungan dan peningkatan produktivitas. Hur et al. (2004) merumuskan indeks produktivitas hijau sebagai rasio antara produktivitas suatu sistem dengan dampaknya terhadap lingkungan yang ditimbulkan. Selanjutnya produktivitas diartikan sebagai rasio antara harga jual (HJ) dan biaya produksi (BP) sedangkan dampak lingkungan terdiri dari limbah gas (LG), konsumsi air (KA) dan limbah padat (LP) serta tingkat pencemaran pada lingkungan (PP) yang masing masing memiliki faktor pembobot (w). Secara matematis dapat dilihat pada Persamaan 1.

Indeks produktivitas Hijau =

$$
\frac{\text { Harga Jual }}{w_{L G} L G+W_{K A} K A+w_{L P} L P+w_{4} P P}
$$

Berkaitan dengan bobot pada dampak lingkungan bobot limbah gas $\left(\mathrm{W}_{\mathrm{LG}}\right)$, bobot konsumsi air $\left(\mathrm{W}_{\mathrm{KA}}\right)$ dan bobot limbah padat $\left(\mathrm{W}_{\mathrm{LP}}\right)$, didasarkan pada bobot yang ditetapkan oleh Environment Sustainable Index (Esty et al., 2005). Marimin et al. (2014) menjabarkan bobot dampak lingkungan tersebut sebagai berikut :

$$
w_{L G}=0,375 ; w_{K A}=0,25 ; w_{L P}=0,125 ; w_{4}=0,25
$$

\section{Inferensi Indeks Produktivitas Hijau dengan Fuzzy Rule-Based}

Fuzzy rule-based diaplikasikan pada penelitian ini untuk mengetahui tingkat produktivitas hijau yang dicapai berdasarkan bahasa linguistik. Fuzzy rule-based diperlukan untuk penilaian yang bersifat vague, ambigu, dan multi penilaian (Marimin et al., 2013) seperti pada penilaian tingkat produktivitas hijau. Inferensi indeks produktivitas hijau ini memerlukan input sistem (fuzifikasi), aturan fuzzy, dan defuzifikasi yang pada penulisan ini mengikuti model yang dikembangkan oleh Hendra (2014).

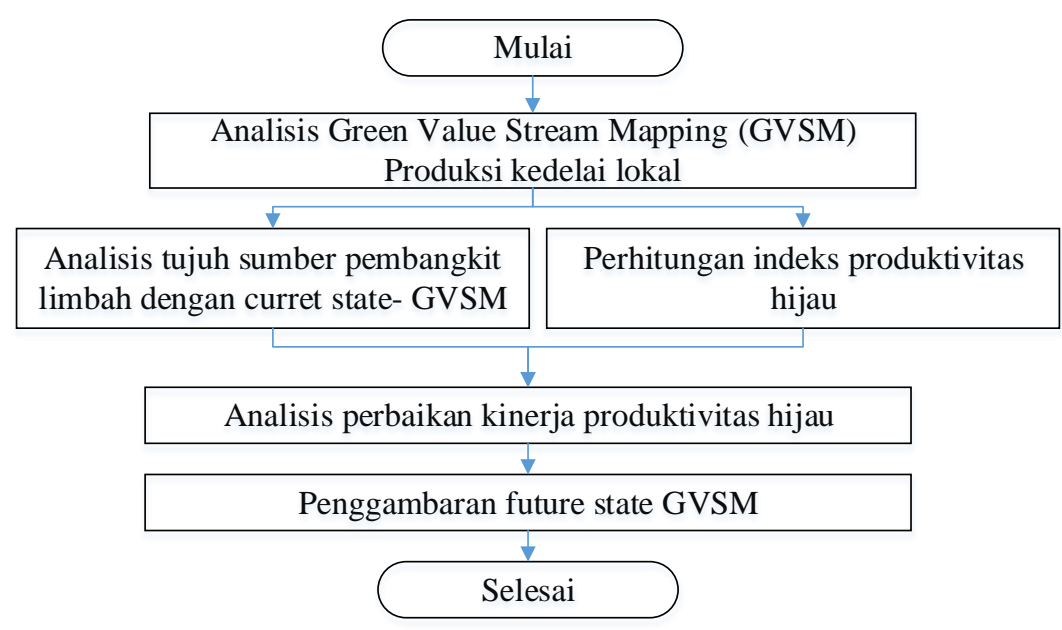

Gambar 2. Diagram alir penilaian produktivitas hijau 
Input fungsi keanggotaan indikator ekonomi mencakup indikator ketepatan benih, penanganan pasca panen, dan biaya produksi sedangkan keanggotaan indikator lingkungan mencakup penanganan limbah berdasarkan informasi dan rekomendasi dari pakar di bidang kedelai. Himpunan fuzzy dari fungsi keanggotaan ketepatan benih, penanganan pasca panen, biaya produksi, dan penanganan limbah dirumuskan sebagai berikut:

a) Ketepatan benih

$$
\begin{array}{ll}
\text { Buruk } & : \text { benih }<7,5 \\
\text { Sedang } & : 6 \leq \text { Benih } \geq 9 \\
\text { Baik } & : 8,5 \leq \text { Benih } \geq 10
\end{array}
$$

b) Ketepatan penanganan pasca panen

$$
\begin{array}{ll}
\text { Buruk } & : \text { Pasca panen }<7.5 \\
\text { Sedang } & : 7 \leq \text { Pasca panen } \geq 8,5 \\
\text { Baik } & : 8 \leq \text { Pasca panen } \geq 10
\end{array}
$$

c) Ketepatan biaya produksi

$$
\begin{array}{ll}
\text { Buruk } & : 2,5 \leq \text { biaya } \leq 10 \\
\text { Sedang } & : 1,5 \leq \text { Biaya } \leq 3,5 \\
\text { Baik } & : 0 \leq \text { biaya } \leq 2
\end{array}
$$

d) Ketepatan penanganan limbah

$$
\begin{array}{ll}
\text { Buruk } & : \text { Pasca panen }<3,5 \\
\text { Sedang } & : 3 \leq \text { Pasca panen } \geq 5 \\
\text { Baik } & : 4 \leq \text { Pasca panen } \geq 10
\end{array}
$$

Ilustrasi cakupan keanggotaan dari parameter ketepatan benih, penanganan pasca panen, biaya produksi, dan penanganan limbah dapat dilihat pada Gambar 3.

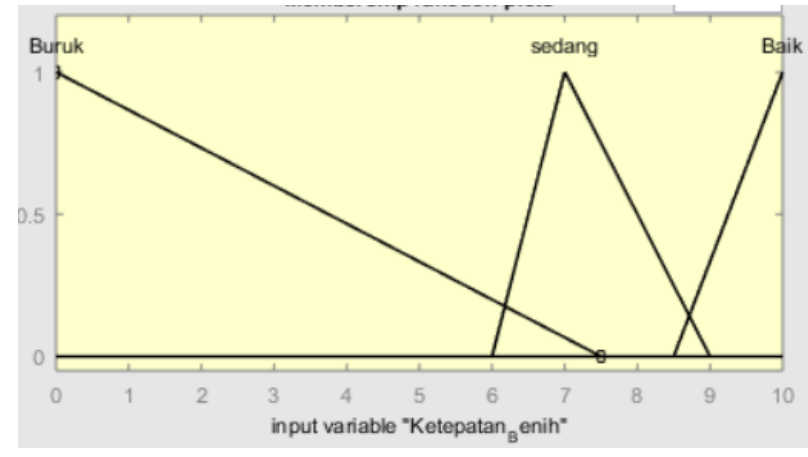

a) Ketepatan benih

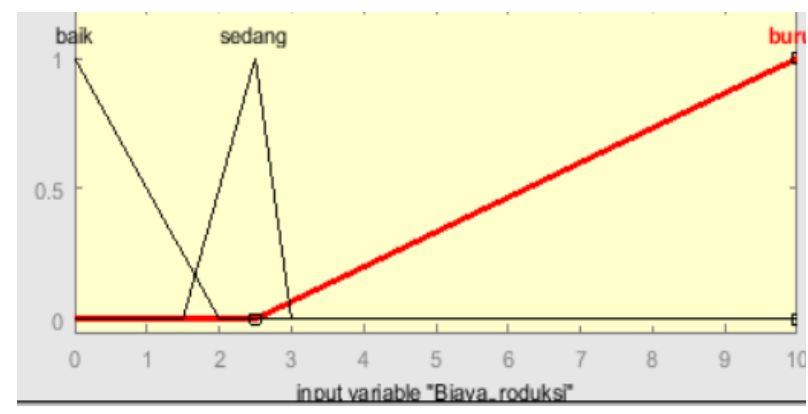

(c). Ketepatan biaya produksi
Aturan fuzzy disusun berdasarkan variabel input dan output fuzzy dengan formula:

IF < Kualitas Benih \& Penanganan pasca panen \& Biaya produksi \& Penanganan limbah> Then Tingkat GPI

Kemungkinan nilai dari penggunaan benih adalah buruk, sedang, dan baik; penanganan pasca pasca panen adalah buruk, sedang, dan baik; biaya produksi adalah buruk, sedang dan baik; serta pemanfaatan dan pengolahan limbah adalah buruk, sedang, dan baik (Gambar 3). Selanjutnya Indeks produktivitas hijau merupakan hasil dari parameter ketepatan benih, penanganan pasca panen, biaya produksi dan penanganan limbah yang dapat diilusatrasikan pada Gambar 4.

\section{HASIL DAN PEMBAHASAN}

\section{Kinerja Produksi dan Produktivitas kedelai Lokal}

Produksi kedelai lokal cenderung menurun sejak terjadi perubahan kebijakan pemerintah mengenai tarif impor kedelai. Pada tahun 1981 1993 tarif impor kedelai sebesar $10 \%$, selanjutnya diturunkan menjadi 5\% pada tahun 1994 - 1997 dan sejak tahun Oktober 1997 kebijakan pemerintah selain memberikan tarif impor kedelai sebesar nol persen juga memberikan keleluasaan bagi importir swasta (Gunawan, 2005).

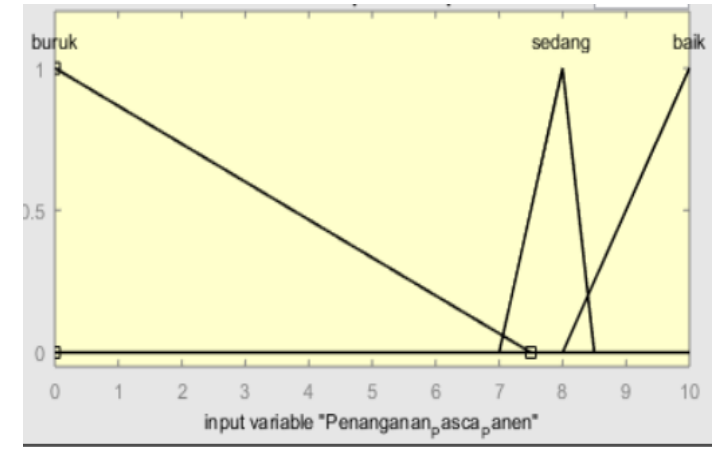

(b) Ketepatan penanganan pasca panen

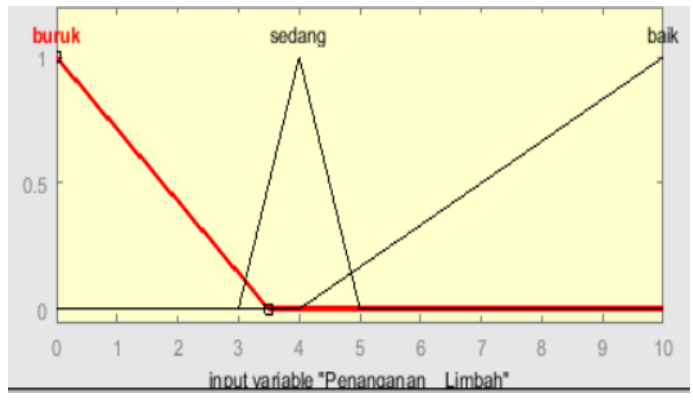

(d). Ketepatan penanganan limbah

Gambar 3. Ilustrasi fungsi keanggotaan parameter indeks produktivitas hijau 
Dampak tersebut menjadikan eksistensi kedelai impor lebih baik dibandingkan dengan kedelai lokal. Hal ini tercermin dari tren penurunan luas panen dan produksi kedelai lokal yang terlihat tahun 1996 sebesar 9,7\%. Penurunan luas panen dan produksi terus terjadi hingga pada tahun 2003 dengan nilai sebesar 5-20\% tahun 2003. Pada tahun 2004 mulai terjadi fluktuasi peningkatan dan penurunan luas panen serta produksi kedelai (Gambar 5).

Produksi kedelai pada tahun 1993 mencapai 1,7 juta ton, kemudian mengalami penurunan bertahap hingga pada tahun 2015 produksi kedelai sebesar 0,96 juta ton. Dengan demikian telah terjadi penurunan produksi cukup besar $(43,58 \%)$ sebagai akibat dari penurunan luas panen. Tren penurunan produksi dan luas tanam kedelai rata-rata tiap tahun masing-masing sebesar $1,52 \%$ dan $2,96 \%$. Namun demikian jika dilihat pada tingkat provinsi terdapat beberapa sentra produksi kedelai yang mengalami pertumbuhan positif baik luas panen maupun produksi yaitu Provinsi Sumatera Selatan $(117,44 \%$, $15,07 \%)$, Banten $(25,73 \%, 176,58 \%)$ dan Jawa Barat $(3,28 \%, 5,46 \%)$ (Tabel 1).

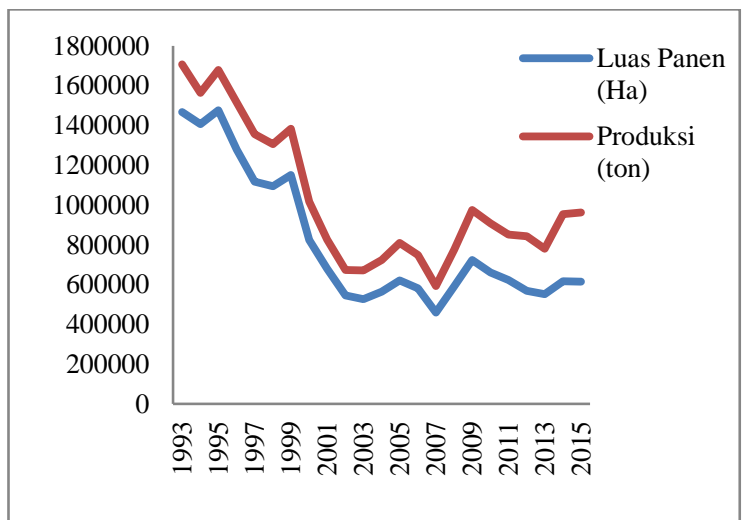

(a)
Penurunan produksi dan luas panen merupakan cerminan dari kurang tertariknya petani untuk menanam kedelai karena usaha tani kedelai dipandang kurang menguntungkan. Hal ini dipicu oleh masuknya kedelai impor dengan harga yang lebih murah karena tarif impor nol persen (Zakiah 2011). Selanjutnya petani beralih pada tanaman palawija lain yang lebih menguntungkan atau memiliki daya saing lebih baik dibadingkan kedelai yaitu komoditas jagung, kacang tanah, dan kacang hijau (Krisdiana, 2011; Nainggolan dan Hendayana, 2014). Faktor lain yang berpengaruh adalah panjangnya rantai pemasaran sehingga mengurangi farmer's share (Muslim dan Darwis, 2012).

Secara matematik produksi kedelai merupakan fungsi dari luas panen dan produktivitas. Luas panen kedelai dari tahun ke tahun cenderung mengalami penurunan, sedangkan tingkat produktivitas kedelai cenderung mengalami peningkatan (Riana dan Hardianto, 2011; Aldilah, 2014). Gambar 6 menunjukkan trend peningkatan produktivitas kedelai nasional dan pertumbuhan peningkatan produktivitas kedelai.

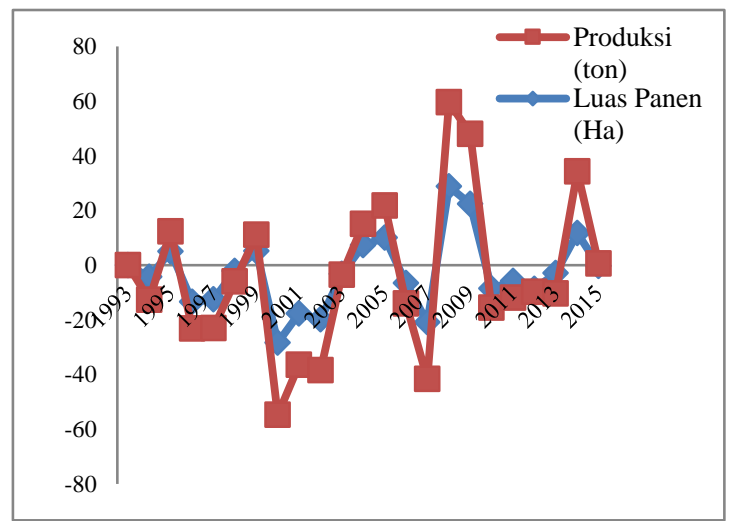

(b)

Sumber : BPS, 2018 (diolah)

Gambar 5. Tren penurunan kedelai nasional Tahun 1993 - 2015, (a) luas panen dan produksi dalam ribuan dan (b) luas panen dan produksi dalam persen

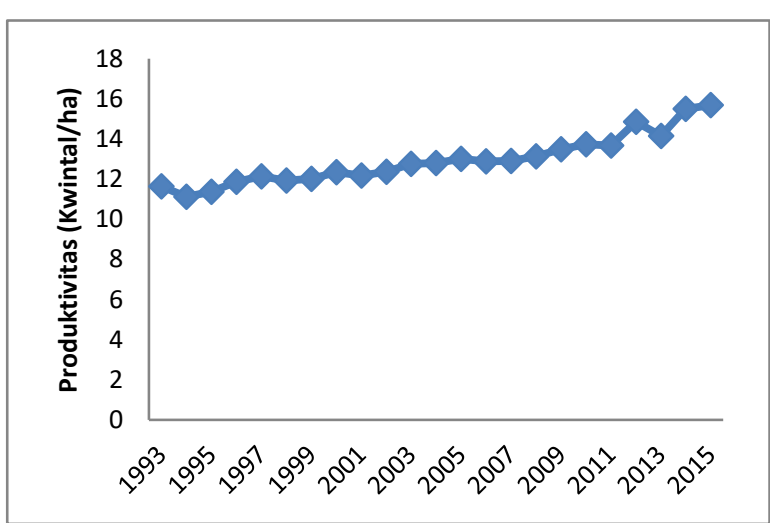

(a)

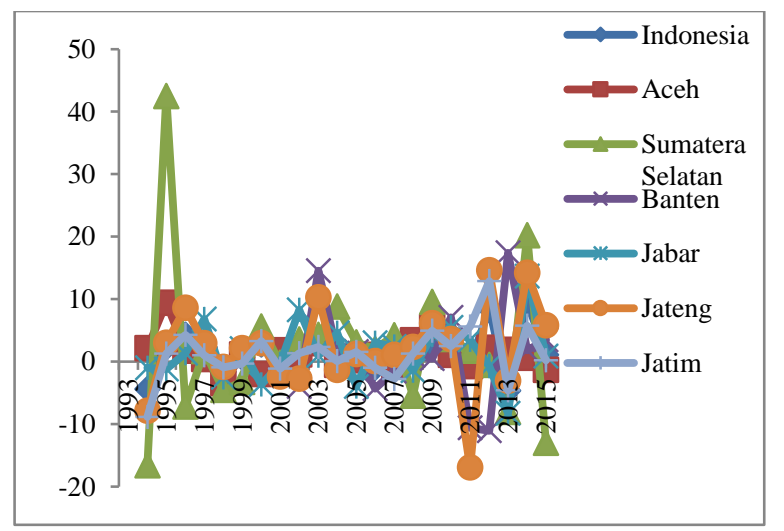

(b)

Gambar 6. Tren peningkatan produktivitas dan pertumbuhan produktivitas kedelai tahun 1993-2015, (a) tingkat nasional (kwintal/ha), (b). tingkat nasional beberapa provinsi di Indonesia (dalam persen) 
Selama kurun waktu 23 tahun (1993-2015) laju pertumbuhan produktivitas kedelai secara nasional rata-rata mencapai $1,42 \%$ per tahun. Keragaman laju pertumbuhan produktivitas tiap provinsi berbeda-beda. Berdasarkan data statistik terhadap enam provinsi penghasil kedelai nasional diperoleh informasi bahwa Provinsi Sumatera Selatan memiliki pertumbuhan produktivitas yang paling tinggi yaitu 2,37\%. Laju pertumbuhan produktivitas yang menonjol terjadi pada tahun 1995 sebesar 42,52\% dan tahun 2014 sebesar 20,25\% (Gambar 6b). Sudaryono et al. (2010) menyatakan selama kurun waktu 6 tahun (2000-2006) produktivitas kedelai mengalami peningkatan yang cukup besar $(86 \%)$ dari produktivitas $0,6-0,7$ ton/ha menjadi 1,2-1,3 ton /ha. Sementara itu Adisarwanto (2007) menyatakan bahwa peningkatan produktivitas kedelai tergolong rendah, dalam kurun waktu 12 tahun (1992-2004) produktivitas kedelai hanya naik sebesar $14 \%$ dari 1,12 ton/ha menjadi 1,20 ton/ha.

Faktor yang berpengaruh terhadap produktivitas tanaman kedelai yaitu kesesuaian agroekologi dan tingkat penerapan teknologi. Sudaryono et al. (2010) menyatakan produktivitas kedelai dipengaruhi oleh tingkat kesesuaian lahan, kesuburan lahan, neraca lengas musiman, pengelolaan hara dan air, pengendalian organisme pengganggu tanaman (OPT), pemeliharaan, dan pascapanen. Agroekologi lahan seperti lahan sawah, lahan pasang surut, dan lahan kering memiliki karakteristik lahan yang berbeda, baik tingkat kesuburan maupun ketersediaan air. Agroekosistem lahan sesuai untuk budi daya kedelai apabila memiliki kecukupan unsur hara dan ketersediaan air (Sudaryono et al., 2010). Tingkat penerapan teknologi budi daya kedelai seperti ketepatan penggunaan varietas, pemupukan, pengendalian hama dan penyakit juga dapat mempengaruhi produktivitas tanaman. Penerapan teknologi budi daya kedelai di tingkat petani belum optimum, terutama dalam penggunaan benih bermutu dan pupuk baik dari segi jenis, jumlah, maupun cara pemberiannya (Zakaria, 2010).
Dalam rangka memenuhi kebutuhan kedelai nasional yang terus meningkat dengan proyeksi peningkatan konsumsi kedelai sebesar 2,44\% per tahun (Sudaryanto dan Swastika, 2007), sementara produksi nasional cenderung stagnan, maka pemerintah terus berupaya meningkatkan produksi kedelai melalui berbagai program antara lain dengan penggunaan benih varietas unggul bermutu; pemberian bantuan sarana pascapanen; dan perbaikan sistem kelembagaan dengan memperbaiki sistem lembaga permodalan serta menguatkan peran gabungan kelompok tani dan kemitraan.

Produktivitas kedelai lokal dan perluasan areal tanam masih memiliki peluang untuk ditingkatkan. Pemanfaatan lahan kering, lahan pasang surut dan lahan sawah yang belum optimal dapat juga dilakukan untuk peningkatan produksi kedelai. Hal penting lain yang perlu dilakukan adalah meningkatkan perbaikan mutu kedelai lokal dan optimalisasi sumber daya serta melakukan perubahan sudut pandang dalam produksi kedelai yang tidak hanya berfokus pada peningkatan produktivitas tetapi juga menjaga kelestarian lingkungan. Dengan demikian kedelai yang dihasilkan dapat dijadikan sebagai bahan baku aneka produk pangan yang bermutu dan sehat sesuai dengan tuntutan gaya hidup saat ini dan masa depan.

\section{Produktivitas Hijau Budi Daya Kedelai}

Tingkat Produktivitas hijau budi daya kedelai dinilai dengan melakukan serangkaian observasi dan pengukuran baik indiktaor lingkungan maupun indikator ekonomi. Pengukuran indikator lingkungan diawali dengan melakukan pengukuran pada sistem produksi yang berpotensi menghasilkan limbah. Wills (2009) menyampaikan terdapat tujuh sumber pembangkit limbah pada masing-masing tahapan produksi yaitu penggunaan energi, konsumi air, matrial terbuang, sampah terbentuk, transportasi, emisi, dan biodiversitas. Total hasil analisis ketujuh sumber pembangkit limbah dari value stream map (current state) dikelompokkan menjadi empat variabel. Gambar 7 menunjukkan produktivitas hijau dengan asumsi produksi kedelai dihitung per musim tanam per ha dalam kawasan lahan kering.

Tabel 1. Rerata luas panen, produktivitas dan produksi serta laju pertumbuhannya selama 23 tahun (1993-2015)

\begin{tabular}{|c|c|c|c|c|c|c|}
\hline \multirow[b]{2}{*}{$\begin{array}{l}\text { Wilayah } \\
\text { /Provinsi }\end{array}$} & \multicolumn{3}{|c|}{ Rerata } & \multicolumn{3}{|c|}{ Laju pertumbuhan (\%) } \\
\hline & $\begin{array}{c}\text { Luas } \\
\text { panen (ha) }\end{array}$ & $\begin{array}{l}\text { Produktivitas } \\
\text { (ton/ha) }\end{array}$ & $\begin{array}{l}\text { Produksi } \\
\text { (ton) }\end{array}$ & $\begin{array}{l}\text { Luas } \\
\text { panen }\end{array}$ & Produktivitas & Produksi \\
\hline Aceh & $55.531,83$ & 1,308 & 69.889 .52 & $(0,84)$ & 1,28 & 0,52 \\
\hline Sumatera Selatan & $9.030,83$ & 1,300 & $11.329,00$ & 117,44 & 2,37 & 15,07 \\
\hline Banten & $4.690,80$ & 1,288 & $5.917,07$ & 25,73 & 1,23 & 176,58 \\
\hline Jawa Barat & $45.010,70$ & 1,359 & $60.076,43$ & 3,28 & 1,55 & 5,46 \\
\hline Jawa Tengah & $121.718,65$ & 1,432 & $169.360,65$ & $(2,17)$ & 1,99 & 0,42 \\
\hline Jawa Timur & $291.882,04$ & 1,334 & $381.448,17$ & $(2,77)$ & 1,31 & $(1,48)$ \\
\hline Indonesia & $814.690,09$ & 1,293 & $1.027 .013,35$ & $(2,96)$ & 1,42 & $(1,52)$ \\
\hline
\end{tabular}

Sumber: BPS 2018 (Diolah) 
Berdasarkan hasil observasi lapang dan wawancara dengan petani, diperoleh informasi bahwa pada budi daya kedelai terdapat aktivitas yang dapat menjadi sumber pembangkit limbah yang dijadikan sebagai indikator lingkungan (EI). Aktivitas dalam produksi kedelai tersebut dapat dikelompokkan menjadi empat bagian yaitu kegiatan pengolahan tanah, penamanan dan perawatan, panen dan pascapanen, serta distribusi. Aktivitas dan nilai pengukuran sumber pembangkit limbah pada lahan tegalan (current state) seperti pada Gambar 8.

Berdasarkan evaluasi sumber pembangkit limbah, penggunaan energi, emisi, dan biodeversitas masih cukup baik dan dapat dipertahankan, sedangkan aspek penggunaan air, material (saprodi), sampah, dan transportasi perlu ditingkatkan kinerjanya. Penggunaan air untuk menunjang kebutuhan produksi petani termasuk katagori pemborosan sehingga menambah input produksi.

$$
\text { Emisi }
$$$$
=22342.61 \mathrm{~kg} \mathrm{CO} 2
$$

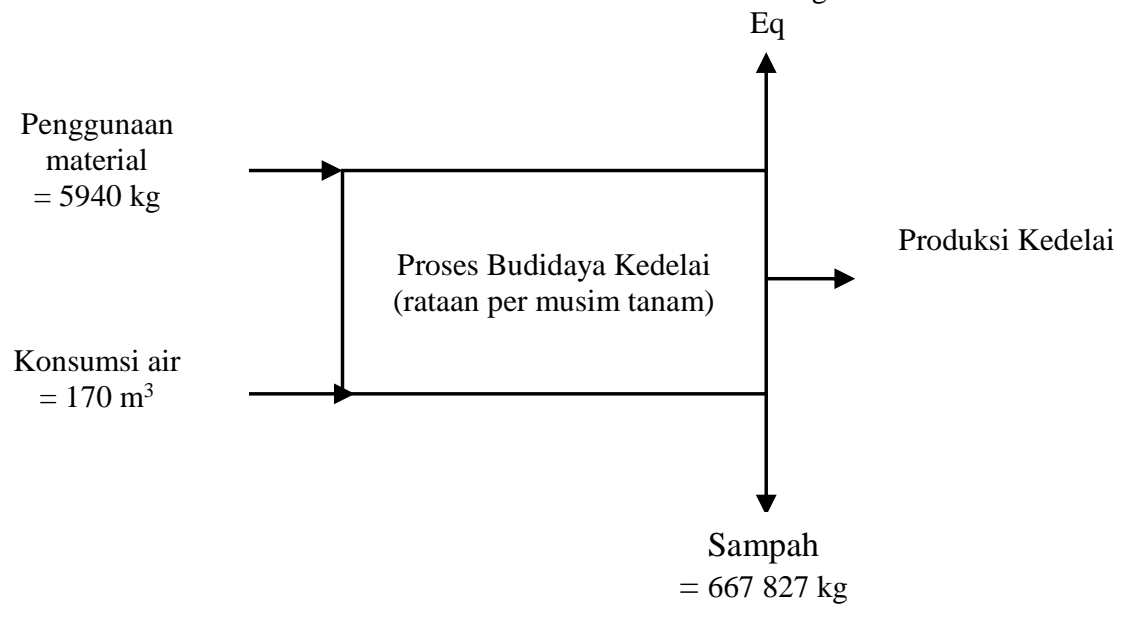

Gambar 7. Aliran material variabel produktivitas hijau budi daya kedelai

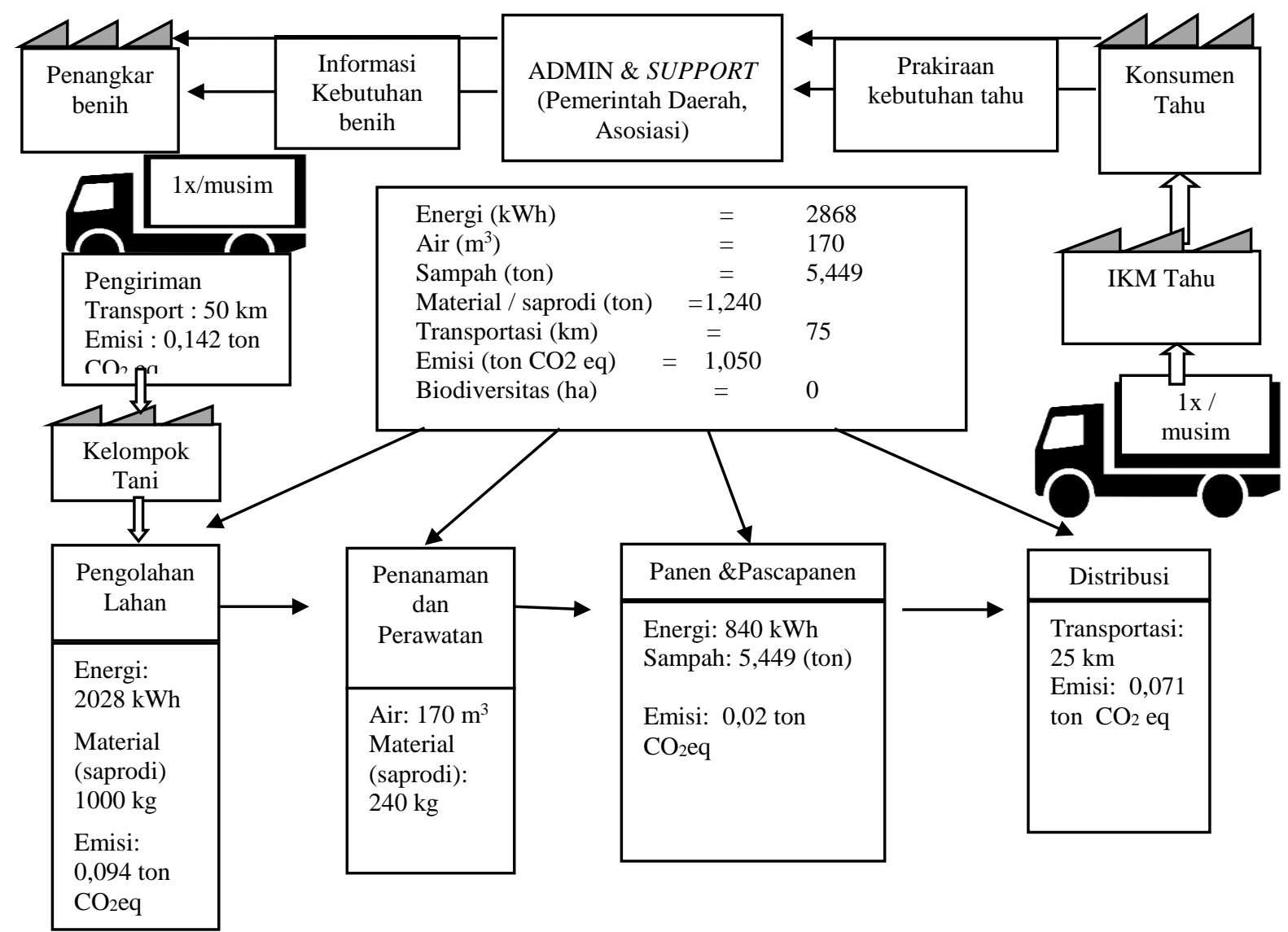

Gambar 8. Green value mapping produktivitas hijau kedelai pada lahan kering 
Petani perlu merencanakan lebih matang lagi dalam mengatur jadwal tanam yang tepat sehingga penggunaan air dapat lebih efisien. Informasi jadwal tanam yang tepat dapat diperoleh dengan mengakses informasi pada situs web Litbang Pertanian berupa KATAM (Kalender Tanam).

Sumber pembangkit limbah pada penggunaan material (saprodi) untuk budi daya kedelai terdiri dari benih, pupuk, dan pestisida. Benih yang digunakan dalam budidaya kedelai memiliki kualitas rendah sehingga mempengaruhi produktivitas tanaman. Kualitas benih tersebut dapat dilihat dari daya tumbuh dan kesesuaian dengan kondisi agroekosistem dan pangsa pasar kedelai yang diinginkan konsumen. Untuk meningkatkan produktivitas kedelai maka diperlukan perbaikan penggunaan mutu benih melalui penumbuhan penangkar benih di wilayah tersebut. Hasil penangkaran digunakan sebagai sumber benih untuk produksi kedelai wilayah secara luas. Sistem Jabalsim yang telah berhasil perlu ditumbuhkan lagi pada sentra-sentra produksi kedelai.

\section{Indeks Produktivitas Hijau}

Indeks produktivitas hijau merupakan rasio dari produktivitas budi daya kedelai terhadap dampak lingkungan yang ditimbulkan. Indeks produktivitas hijau mencerminkan kemampuan sistem produksi untuk menghasilkan satu unit dengan risiko dampak lingkungan yang ditimbulkan. Semakin tinggi nilai indeks produktivitas hijau menunjukkan semakin baiknya sistem produksi yang dibangun oleh industri (Gandhi et al., 2006).

Hasil pengukuran terhadap sumber pembangkit limbah pada produksi kedelai diperoleh nilai limbah gas 1,050 ton (LG), konsumsi air 0,017 ton, limbah padat 5,449 (LP), dan kerusakan terhadap biodeversitas 0 ton (PP). Selanjutnya untuk mengukur dampak lingkungan yang ditimbulkan dengan penjumlahan tiga bobot variabel lingkungan indeks produktivitas hijau yang berasal dari nilai pembobotan ESI (Gandhi et al., 2006). Nilai indikator lingkungan budi daya kedelai sebagai berikut:

$$
\begin{aligned}
& \text { Indikator lingkungan }(E I)=(0,375 \times 1,050)+ \\
& (0,25 \times 0,017)+(0,125 \times 6,689)+(0,25 \times 0)=1,23
\end{aligned}
$$

Melalui perhitungan tersebut, diketahui nilai dampak lingkungan yang ditimbulkan dalam setiap ha lahan sebesar 5,449 ton sampah. Berdasarkan wawancara dengan pelaku usaha tani kedelai, diketahui bahwa biaya produksi kedelai yang mencakup biaya sarana produksi dan tenaga kerja setiap musim tanam sebesar Rp 4.650.000. Sementara produksi tiap ha mencapai 1,2 ton dengan harga jual kedelai di pasaran sebesar Rp 6.000 per $\mathrm{kg}$, maka diperoleh penerimaan sebesar $\mathrm{Rp}$ 7.200.000. Dengan demikian nilai perbandingan perolehan pendapatan dan keseluruhan biaya adalah 1,54. Indeks produktivitas hijau atau green productivity index (GPI) diperoleh melalui rasio indikator ekonomi dengan lingkungan (Hur et al. 2004). Hasil perhitungan indeks produktivitas hijau sebagai berikut:

$$
\text { GPI }=(1,54 / 1,23)=1,25
$$

Pengukuran produktivititas hijau budi daya kedelai pada lahan sawah dan lahan hutan dilakukan sama seperti halnya dengan pengukuran produktivitas hijau pada lahan tegalan. Keragaman hasil pengukuran indikator lingkungan, indikator ekonomi, dan indeks produktivitas hijau pada berbagai tipe lahan budi daya kedelai di lahan tegalan, lahan sawah, dan lahan hutan tersaji pada Tabel 2 .

\begin{tabular}{|c|c|c|c|}
\hline Uraian & Lahan tegalan & Lahan sawah & Lahan hutan \\
\hline \multicolumn{4}{|l|}{ Indikator lingkungan } \\
\hline Energi $(\mathrm{kWh})$ & 2868,00 & 840,00 & 840,00 \\
\hline Air (ton) & 0,017 & 0,00 & 0,00 \\
\hline Sampah (ton) & 5,45 & 5,30 & 5,40 \\
\hline Material (saprodi) (ton) & 1,24 & 1,24 & 1,24 \\
\hline Transportasi $(\mathrm{km})$ & 75,00 & 75,00 & 95,00 \\
\hline Emisi (ton $\mathrm{CO}_{2} \mathrm{Eq}$ ) & 1,05 & 0,86 & 0,75 \\
\hline Biodiversitas (ha) & 0,00 & 0,00 & 0,00 \\
\hline Nilai Lingkungan & 1,23 & 1,14 & 1,11 \\
\hline \multicolumn{4}{|l|}{ Indikator ekonomi } \\
\hline Biaya tenaga kerja $(\mathrm{Rp})$ & $3.450 .000,00$ & $2.650 .000,00$ & $2.900 .000,00$ \\
\hline Biaya Sarana produksi (Rp) & $1.200 .000,00$ & $950.000,00$ & $1.000 .000,00$ \\
\hline Total biaya $(\mathrm{Rp})$ & $4.650 .000,00$ & $3.600 .000,00$ & $3.900 .000,00$ \\
\hline Produksi (ton) & $1.200,00$ & $1.400,00$ & $1.350,00$ \\
\hline Harga jual (Rp) & $6.000,00$ & $6.000,00$ & $6.000,00$ \\
\hline Total Penerimaan (Rp) & $7.200 .000,00$ & $7.200 .000,00$ & $7.200 .000,00$ \\
\hline Nilai Ekonomi & 1,55 & 2,00 & 1,85 \\
\hline Indeks Produktivitas Hijau & 1,25 & 1,75 & 1,66 \\
\hline
\end{tabular}

Tabel 2. Keragaman indikator lingkungan dan ekonomi serta indeks produktivitas hijau pada budidaya tipe lahan tegalan, sawah dan hutan 
Data pada Tabel 2. menunjukkan bahwa indeks produktivitas hijau berbeda pada masingmasing lahan. Perbedaan indeks produktivitas hijau dipengaruhi oleh indikator ekonomis yaitu input dan output produksi. Lahan sawah dan hutan memiliki input produksi yang relatif lebih rendah dibandingkan dengan lahan tegalan. Efisiensi biaya produksi berbeda terutama pada penerapan teknologi pengolahan lahan. Pada lahan sawah dan hutan tidak dilakukan pengolahan tanah sempurna sedangkan pada lahan tegalan dilakukan pengolahan tanah sempurna. Penataan lahan yang dilakukan berupa pembuatan drainase agar tidak terjadi genangan air pada saat hujan. Kinerja produktivitas pada ketiga lahan tersebut masih dapat ditingkatkan terutama pada aspek benih, penanganan pascapanen, serta penanganan limbah.

\section{Model Peningkatan Produktivitas Hijau}

Produktivitas hijau sebagai salah satu strategi rangka peningkatan kinerja produktivitas dan lingkungan untuk pembangunan sosial ekonomi secara keseluruhan (Marimin, 2015). Dalam implementasinya produktivitas hijau pada kedelai dapat dilakukan melalui perbaikan sistem penyediaan benih, penerapan kultur teknis budi daya dan pascapanen, pengelolaan dan pemanfaatan limbah, serta sistem logistik yang efektif dan efisien. Konsep peningkatan produktivitas hijau memiliki persamaan dengan konsep pendekatan pengelolaan tanaman terpadu (PTT) yang dijadikan sebagai program kementrian pertanian dalam peningkatan produksi padi, jagung dan kedelai. Pengelolaan tanaman terpadu merupakan strategi untuk peningkatan hasil dan pendapatan petani melalui penggunaan sumberdaya alam serta masukan produksi yang efisien dan berkelanjutan, dengan azas integrasi, interaksi, dinamis dan partisipatif (Puslitbangtan, 2009b dalam Jamil dan Widiarta, 2016). Persamaan pendekatan tersebut terletak pada strategi dalam meningkatkan produktivitas dan pendapatan serta optimalisasi sumberdaya lahan. Pada aspek kepedulian terhadap dampak lingkungan pendekatan produktivitas hijau mendapatkan perhatian lebih menonjol. Hal tersebut tercermin dari metode dalam pemetaan dan pengukuran terhadap dampak lingkungan dalam bentuk nilai indeks produktivitas hijau .

Dalam peningkatan produktivitas hijau dilakukan melalui serangkaian tahapan mulai faktor pendorong berupa trend gaya hidup sehat sampai dengan evaluasi program yang tercermin pada Gambar 9. Implementasi peningkatan produktivitas hijau diperlukan perbaikan dan peningkatan kinerja yang terbagi menjadi tiga aspek yaitu kinerja produksi benih, kinerja penanganan pascapanen, serta kinerja penanganan dan pengolahan limbah seperti pada Tabel 3.

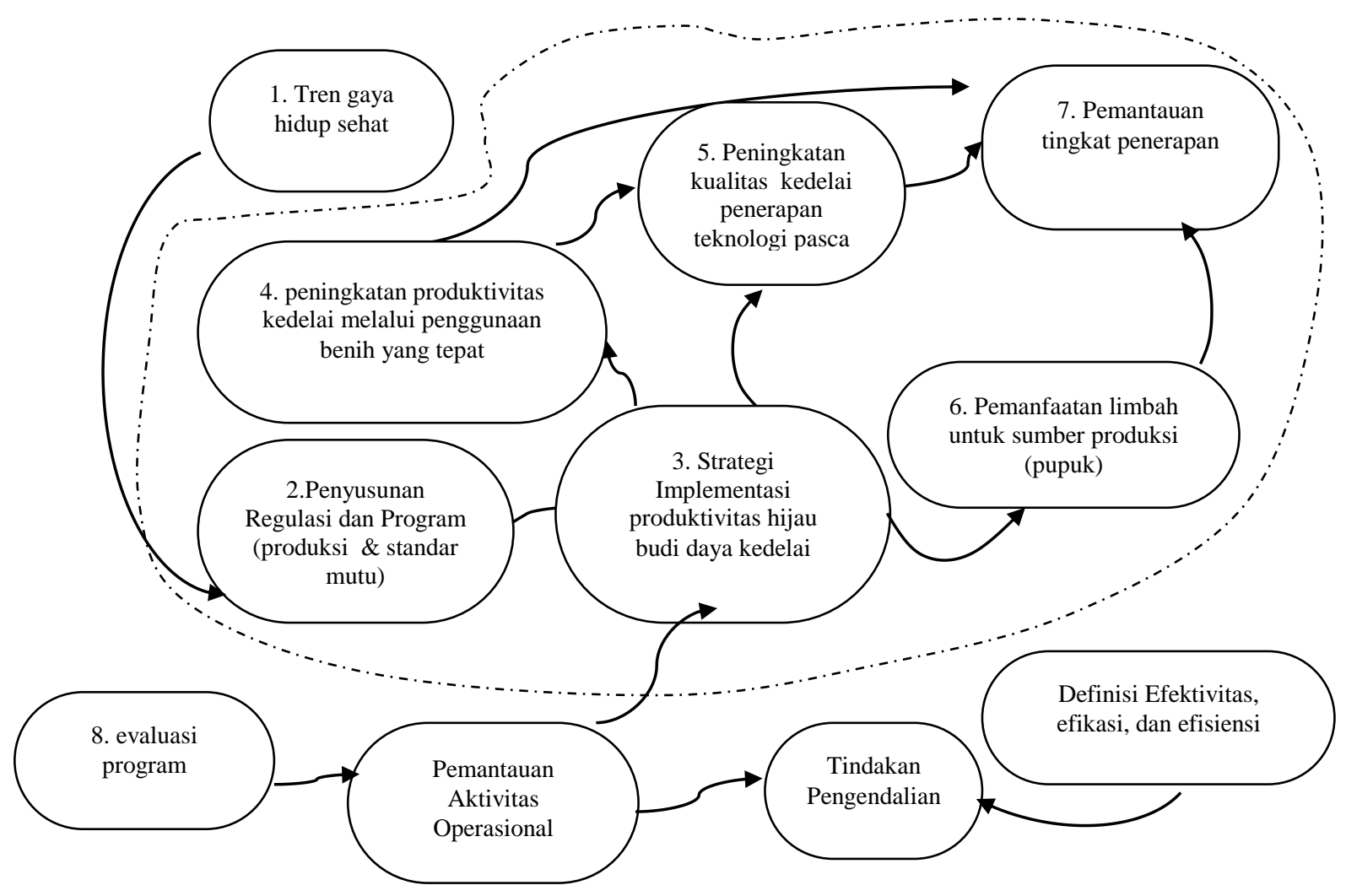

Gambar 9. Model produktivitas hijau kedelai 
Tabel 3. Peningkaan kinerja model produktivitas hijau budidaya kedelai

\begin{tabular}{|c|c|c|c|c|c|}
\hline Kegiatan & $\begin{array}{c}\text { Model } \\
\text { kenyataan }\end{array}$ & Pelaksanaan & Pelaku & Penilaian & Alternatif \\
\hline $\begin{array}{l}\text { Produksi } \\
\text { benih }\end{array}$ & $\begin{array}{l}\text { Model } \\
\text { perbaikan } \\
\text { sistem } \\
\text { produksi } \\
\text { benih }\end{array}$ & $\begin{array}{l}\text { Rekayasa } \\
\text { kelembagaan, } \\
\text { sistem informasi } \\
\text { dan produksi benih }\end{array}$ & $\begin{array}{l}\text { Penangkar } \\
\text { benih, } \\
\text { BPSB }\end{array}$ & $\begin{array}{l}\text { Belum handal / } \\
\text { keterbatasan } \\
\text { informasi dan } \\
\text { pasar }\end{array}$ & $\begin{array}{l}\text { Model penangkaran } \\
\text { benih per wilayah } \\
\text { (Jabalsim) }\end{array}$ \\
\hline $\begin{array}{l}\text { Penanganan } \\
\text { pascapanen }\end{array}$ & $\begin{array}{l}\text { Model } \\
\text { penanganan } \\
\text { pasca panen }\end{array}$ & $\begin{array}{l}\text { Penyediaan sarana } \\
\text { pasca panen dan } \\
\text { rekayasa } \\
\text { kelembagaan }\end{array}$ & $\begin{array}{l}\text { Petani dan } \\
\text { Dinas } \\
\text { Pertanian }\end{array}$ & $\begin{array}{l}\text { Belum } \\
\text { terbangun } \\
\text { kesadaran dan } \\
\text { manfaat nilai } \\
\text { tambah }\end{array}$ & $\begin{array}{l}\text { Model penanganan } \\
\text { pasca panen efektif } \\
\text { dan efisien }\end{array}$ \\
\hline $\begin{array}{l}\text { Penanganan } \\
\text { limbah dan } \\
\text { pengolahan } \\
\text { limbah }\end{array}$ & $\begin{array}{l}\text { Model } \\
\text { perbaikan } \\
\text { dan } \\
\text { penanganan } \\
\text { limbah }\end{array}$ & $\begin{array}{lr}\text { Pembinaan } & \text { dan } \\
\text { pelatihan } & \text { serta } \\
\text { komersialisasi } & \end{array}$ & $\begin{array}{l}\text { Dinas } \\
\text { pertanian, } \\
\text { Litbang } \\
\text { pertanian }\end{array}$ & $\begin{array}{l}\text { Keterbatasan } \\
\text { informasi dan } \\
\text { nilai tambah }\end{array}$ & $\begin{array}{l}\text { Model penanganan } \\
\text { limbah yang tepat }\end{array}$ \\
\hline
\end{tabular}

\begin{abstract}
Produktivitas hijau kedelai dapat ditingkatkan melalui inovasi teknologi dan manajemen sehingga yang semula memiliki indeks produktivitas hijau rendah (kinerja buruk) mengalami peningkataan indeks kinerjanya menjadi katagori baik (Gambar 10). Peningkatan kinerja penggunaan benih (varietas) dan budidaya memiliki kontribusi besar terhadap peningkatan produktivitas kedelai. Potensi peningkatan produktivitas melalui inovasi tersebut dapat dapat mencapai $30-40 \%$ (hasil simulasi). Sementara itu pada penerapan pengelolaan tanaman terpadu (PTT) melalui penggunaan benih dan budidaya spesifik lokasi pada lahan sawah dapat meningkatkan produktivitas kedelai mencapai 33\% dan pendapatan 86\% (Sarwanto, 2007). Penerapan PTT pada lahan sawit dapat meningkatkan produktivitas kedelai dan pendapatan masing-masing $96 \%$ dan 100\% (Marwoto et al., 2012).

Peningkatan kualitas kedelai melalui inovasi teknologi dan management pasca panen dengan mengoptimalkan alat dan mesin pertanian. Petani dan pedagang pengumpul umumnya kurang memperhatikan terhadap mutu kedelai. Akibatnya dari hal tersebut harga lokal lebih rendah dibandingkan dengan kedelai impor. Penerapan teknologi pasca panen masih rendah terutama pada pengeringan dan sortasi. Kedelai hasil panen biasanya tidak dilakukan pengeringan hingga kadar air sesuai standar penyimpanan akibat nya memiliki umur simpan yang singkat. Petani umumnya juga tidak melakukan sortasi sehingga kedelai yang di pasok ke industri memiliki tingkat kotoran yang tinggi. Melalui peningkatan kinerja pasca panen diharapkan terjadi peningkatan kualitas kedelai dan meningkatkan harga jual.
\end{abstract}

\section{Simulasi Peningkatan Produktivitas Hijau}

Peningkatan produktivitas hijau yang dilakukan melalui perbaikan kinerja penerapan penggunaan benih, teknologi pascapanen, penanganan limbah, dan efisiensi input produksi dapat meningkatkaan indeks produktivitas hijau (GPI). Tabel 4 menunjukkan aturan fuzzy prediksi peningkatan produktivitas hijau.

Untuk mengetahui capaian produktivitas hijau dalam budi daya kedelai dapat dilakukan dengan simulasi menggunakan fuzzy inference system (FIS). Peningkatan produktivitas hijau dilakukan dengan cara memberikan input parameter ketepatan benih, penanganan pascapanen, biaya produksi, dan penanganan limbah sesuai dengan tingkat nilai masing-masing parameter sehingga dihasilkan tingkat produktivitas hijau sesuai dengan perbaikan kinerjanya. GPI yang semula masuk dalam katagori buruk atau sedang, dengan perbaikan kinerja pada empat parameter yang awalnya rendah (buruk) mengalami peningkatan menjadi tinggi (baik). Gambar 10 menunjukkan model FIS untuk peningkatan produktivitas hijau kedelai lokal.

\section{Implikasi Kebijakan}

Pendekatan produktivitas hijau merupakan strategi dalam rangka peningkatan produktivitas dan kualitas kedelai lokal dengan tujuan meningkatkan nilai tambah bagi pelaku yang terlibat dalam agribisnis kedelai yaitu petani dan pengumpul. Kinerja produktivitas dan kualitas kedelai lokal dapat meningkat jika mengimplemntasikan pendekatan ini sehingga mampu bersaing dengan kedelai impor khususnya untuk memenuhi kebutuhan industri pengolahan tahu. Guna menunjang kelangsungan produktivitas hijau diperlukan peran serta pemerintah khususnya dalam membangun kerja sama yang baik dan menguntungkan antara petani dengan industri pengolahan kedelai untuk meningkatkan kinerja distribusi. Rekayasa kelembagaan distribusi diharapkan dapat meningkatkan nilai tambah secara proporsional bagi pelaku usaha baik petani maupun pengrajin tahu dan tempe. 
Tabel 4. Aturan fuzzy prediksi produktivitas hijau kedelai

\begin{tabular}{cccccc}
\hline No & Benih & Pascapanen & Biaya & Limbah & GPI \\
\hline 1 & Baik & Baik & Baik & Baik & Baik \\
2 & Baik & Baik & Baik & Sedang & Baik \\
3 & Baik & Baik & Baik & Buruk & Sedang \\
4 & Baik & Baik & Sedang & Baik & Baik \\
5 & Baik & Baik & Sedang & Sedang & Baik \\
6 & Baik & Baik & Sedang & Buruk & Sedang \\
7 & Baik & Baik & Buruk & Baik & Sedang \\
. & $\cdot$ & $\cdot$ & $\cdot$ &. & $\cdot$ \\
28 & Sedang & Baik & Baik & Baik & Baik \\
29 & Sedang & Baik & Baik & Sedang & Baik \\
30 & Sedang & Baik & Baik & Buruk & Sedang \\
31 & Sedang & Baik & sedang & Baik. & Sedang \\
32 & Sedang & Baik & Sedang & Sedang & Sedang \\
. & $\cdot$ & $\cdot$ &. &. & $\cdot$ \\
78 & Buruk & Buruk & Sedang & Buruk & Buruk \\
79 & Buruk & Buruk & Buruk & Baik & Buruk \\
80 & Buruk & Buruk & Buruk & Sedang & Buruk \\
81 & Buruk & Buruk & Buruk & Buruk & Buruk \\
\hline
\end{tabular}

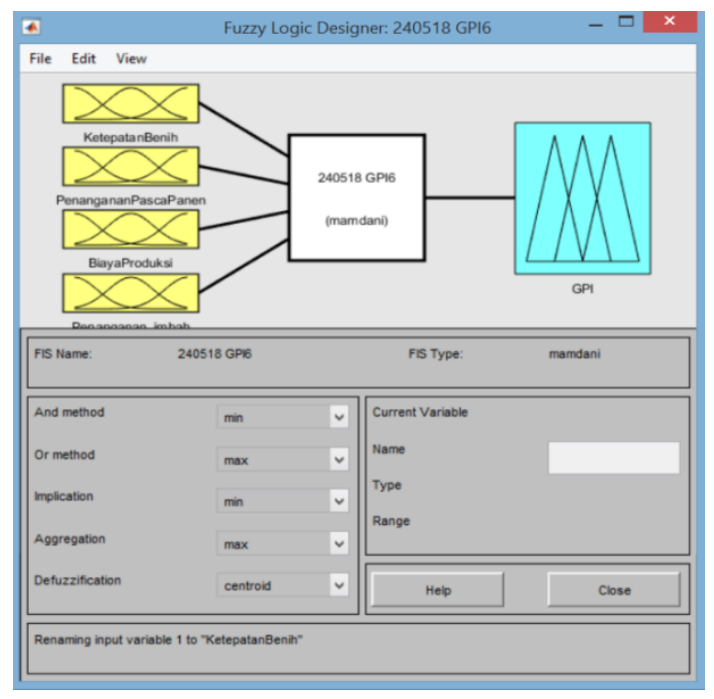

(a) Kerangka model

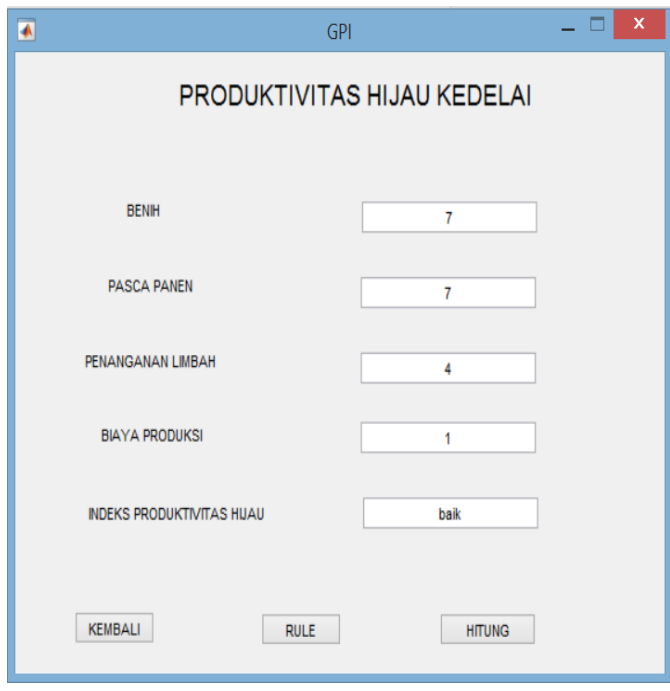

(b) Hasil simulasi

Gambar 10. Model FIS untuk peningkatan produktivitas hijau kedelai lokal

\section{KESIMPULAN DAN SARAN}

\section{Kesimpulan}

Produktivitas dan kualitas kedelai lokal masih rendah dan perlu ditingkatkan agar dapat bersaing dengan kedelai impor. Indeks produktivitas hijau kedelai lokal lahan tegalan, sawah dan hutan masing-masing sebesar 1,25, 1,75 dan 1,66 dengan katagori rendah, sedang dan sedang. Strategi peningkatan indeks produktivitas hijau dapat dilakukan melalui peningkatan kinerja dalam aspek penggunaan benih melalui penumbuhan penangkar benih pada sentra produksi kedelai, penanganan pascapanen, serta pemanfaatan dan pengolahan limbah. Peningkatan dilakukan dengan cara pemilihan varietas yang tepat dan manajemen produksi benih yang handal, penggunaan dan pengelolaan alat mesin pascapanen (threser), serta pembangunan kelompok pengolahan limbah kedelai.

\section{Saran}

Agar implementasi produktivitas hijau budi daya kedelai mampu bersaing dengan kedelai impor, maka disarankan untuk dibuat sertifikat dan dibangun kerja sama dengan industri olahan kedelai yang menerapkan produktivitas hijau sehingga dapat dihasilkan produk dengan label produk hijau (green product) yang memenuhi kebutuhan konsumen. Melalui label tersebut diharapkan akan memperoleh harga jual produk yang lebih baik dan memberikan nilai tambah bagi produsen kedelai serta hasil olahannya. 


\section{DAFTAR PUSTAKA}

Adisarwanto. 2007. Peluang peningkatan produktivitas kedelai di lahan sawah. Iptek Tanaman pangan. 2 (2): 205-213.

Esty. Daniel C, Srebotnjak LM, Tanja, Sherbinin, Alexander de, 2005. Enviromental susteainability index. Benchmarking National Enviromental Stewardship, Yale Center for Enviromental Law and Policy, New Heaven

Gandhi N, Mohan DV, Selladurai P, Santhi. 2006. Green productivity indexing: A practical step towards integrating environmental protection into corporate performance. International Journal of Productivity and Performance Management. 55 (7): 594-606.

Gunawan E. 2005. Dampak perdagangan bebas terhadap daya saing dan profitabilitas usahatani kedelai di Jawa Timur dan Sulawesi Selatan. [Thesis]. Jakarta: Universitas Indonesia.

Ginting E, Antarlina SS, Widowati S. 2009. Varietas kedelai untuk bahan industri pangan. Jurnal Litbang Pertanian. 28 (3): 79-87.

Hur T, Kim I, dan Yamamoto R. 2004. Measurement of green productibity and its improvement. Journal of Cleaner Production. 12 (7): 673683.

Karmana IW. 2009. Adopsi tanaman transgenik dan beberapa aspek pertimbangannya. Ganec Swara. 3 (2): 12-21.

Krisdiana R. 2011. Daya saing dan faktor determinan usaha tani kedelai di lahan sawah. Penelitian Pertanian Tanaman Pangan. 31 (1): 6-12.

Marimin, Darmawan MA, Machfud, Putra MPIF, Wiguna B. 2014. Value chain analysis for green productivity improvement in the natural rubber supply chain: a case study. Journal of Cleaner Production. XXX (2014): $1-11$.

Marimin, Djatna T, Suharjito, Hidayat S, Utama DN, Astuti R, Martini S. 2013. Teknik dan Analisis Pengambilan Keputusan Fuzzy dalam Manajemen Rantai Pasok. Bogor (ID): IPB Press.
Marimin, Machfud, Darmawan A, Martini S, Rukmayadi D, Bangkit W, Islam MP, Adhi W. 2015. Teknik dan Aplikasi Produktivitas Hijau (Green Productivitiy) pada Agroindustri. Bogor (ID): IPB Press.

Muslim E, Diah R I. 2014. Analisis pengaruh ecolabel terhadap kesadaran konsumen untuk membeli green produc. Jurnal Manajemen Teknologi. 13 (1):66-80.

Nainggolan dan Hendayana. 2014. Prospek swasembada kedelai Indonesia. Pangan. 23 (1): 83-92.

Riana FD dan Hardiyanto I. 2011. Analisis peramalan konsumsi kedelai (Glycine Max L.) di Indonesia Tahun 2010-2019. AGRISE. XI (1): 9-18.

Saxena AK, Bhardwaj KD, dan Sinha KK. 2003. Suistainable growth through green productivity, a case of edible oil industry in India. International Energy Journal. 4 (1): 81-91.

Supadi. 2009. Dampak impor kedelai berkelanjutan terhadap ketahanan pangan. Analisis Kebijakan Pertanian. 7 (1): 87-103.

Sumarno. 2010. Green agriculture dan green food sebagai branding dalam usaha pertanian. Forum Penelitian Agroekonomi. 28 (2): 8190.

Sudaryono, Taufik A, dan Wijanarko A. 2010. Peluang Peningkatan Produksi Kedelai di Indonesia. Teknik Produksi dan Pengembangan Puslitbangtan. 130-167.

Tasra, E Ginting, Gatot. 2012. Menuju swasembada Kedelai Melalui Penerapan Kebijakan Strategis. Iptek Tanaman Pangan. 7 (1): 4757.

Wills B. 2009. Green Intention: Creating a Green Value Stream to Compate and Win. New York (US): CSC Press.

Zakaria AK, Sejati WK, dan Kustiar R. 2010. Analisis dayasaing komoditas kedelai menurut agro ekosistem: kasus di tiga provinsi di indonesia. Jurnal Agro Ekonomi. 28 (1):21-37.

Zakiah. 2011. Dampak impor terhadap produksi kedelai nasinoal. Agrisep 12 (1): 1-10. 